\title{
FORMING ANALYSIS OF STEEL BALL BEARINGS MADE WITH WARM SKEW ROLLING
}

\author{
ANALIZA OBLIKOVANJA JEKLENIH LEŽAJNIH KROGEL S \\ POŠEVNIM TOPLIM VALJANJEM
}

\author{
Yuanming Huo ${ }^{\text {* }}$, Tao He ${ }^{1}$, Baoyu Wang ${ }^{2}$, Zhenhua Zheng ${ }^{2}$, Wanbo Yang ${ }^{1}$, \\ Yujia Hu${ }^{1}$, Menglan Shen ${ }^{1}$ \\ ${ }^{1}$ School of Mechanical and Automotive Engineering, Shanghai University of Engineering Science, Shanghai 201620, China \\ ${ }^{2}$ School of Mechanical Engineering, University of Science and Technology Beijing, Beijing 100083, China
}

Prejem rokopisa - received: 2019-09-05; sprejem za objavo - accepted for publication: 2019-12-23

Skew rolling (SR) is a special metal-forming technique for producing spherical components. In order to analyze the forming mechanism for bearing steel balls (BSBs), an FE simulation of warm SR was conducted using commercial FEM software (Deform-3D) to predict the distribution of plastic strain, strain rate, temperature and stress for BSBs with a diameter of $\phi 30 \mathrm{~mm}$. A warm-SR experiment was performed to validate the FE simulation. In this work, SR process parameters were designed to form BSBs with a diameter of $\phi 30 \mathrm{~mm}$. The experimental results show that warm SR allows the production of spherical BSBs with a high manufacturing quality. Comparing the experimental and predicted results, we found that the predicted BSBs were consistent with the experimental BSBs. Based on the experimental investigation and numerical simulation, the BSB formation mechanism during the warm-SR process was revealed.

Keywords: steel ball bearings, skew rolling, forming simulation, experimental investigation

Tehnološki postopek poševnega valjanja je posebna tehnika oblikovanja za izdelavo kovinskih komponent krogličnih oblik. Da bi analizirali mehanizme oblikovanja jeklenih ležajnih krogel, so avtorji članka izvajali simulacije poševnega toplega valjanja na osnovi metode končnih elementov (FEM), s komercialnim programskim orodjem Deform-3D. Tako so lahko napovedali porazdelitev plastičnih deformacij, hitrosti deformacije, temperature in napetosti v jeklenih ležajnih kroglah premera $\phi 30$ mm. Zato, da bi ovrednotili FEM-simulacije, so izvedli tudi praktične preizkuse toplega poševnega valjanja. V tej raziskavi so dizajnirali procesne parametre izbranega postopka za oblikovanje jeklenih ležajnih krogel premera $\phi 30 \mathrm{~mm}$. Rezultati eksperimenta so pokazali, da je s toplim poševnim valjanjem možno izdelati visokokvalitetne jeklene ležajne krogle. Primerjava rezultatov eksperimenta in rezultatov FEM-simulacij je pokazala njihovo dobro ujemanje. Na osnovi eksperimentov in FEM simulacij, so avtorji lahko tudi odkrili mehanizme nastajanja jeklenih ležajnih krogel med poševnim toplim valjanjem.

Ključne besede: jeklene ležajne krogle, poševno valjanje, simulacija oblikovanja, eksperimentalna raziskava

\section{INTRODUCTION}

As one kind of basic parts in the machinery-equipment industry, bearings have been widely used in many fields, such as mechanical manufacturing, railway transportation, aerospace and automotive manufacturing, etc. ${ }^{1}$ Microcracks are usually formed within an BSB under the alternating load, which requires high-cycle fatigue strength. A breakage is the main reason for a failure of a bearing. ${ }^{2}$ Therefore, researchers are especially interested in finding the way of producing highperformance BSBs.

The performance of BSBs depends on the deformation process. The traditional manufacturing methods include cold forging, hot forging, cutting and casting. ${ }^{3}$ Cold forging is suitable to form BSBs whose diameter is less than $20 \mathrm{~mm}$. Steel balls whose diameter is larger than $20 \mathrm{~mm}$ are formed with hot forging. ${ }^{4}$ Cutting and casting are often adapted to form specially large steel

*Corresponding author's e-mail:

yuanming.huo@sues.edu.cn (Yuanming Huo) balls. Traditionally, cold forging and hot forging are more often selected to form BSBs.

$\mathrm{SR}$ is a manufacturing method whose working principle is shown in Figure 1. ${ }^{5}$ The SR system includes the top and bottom plates, a workpiece and two rollers with a spiral groove. In the feeding direction, the height and width of the raised edges on both sides of the spiral groove vary from low and narrow to high and broad. In addition, the axis of the two rollers intersect each other vertically to keep the given roller angle. In the process of SR, two rollers rotate simultaneously in the same direction. Under the influence of friction and squeezing, the workpiece rotates against the rotary direction of the rollers. The local radial compression and axial extension take place within the workpiece. Such local accumulative deformation leads to the formation of BSBs within the spiral groove. One BSB can be formed after one revolution of the two rollers. ${ }^{6}$ Compared with traditional forging and casting, the SR technique has significant advantages, including a high production efficiency, savings of the materials and energy, low costs, a lower working load, a long roller life, a good working environ- 


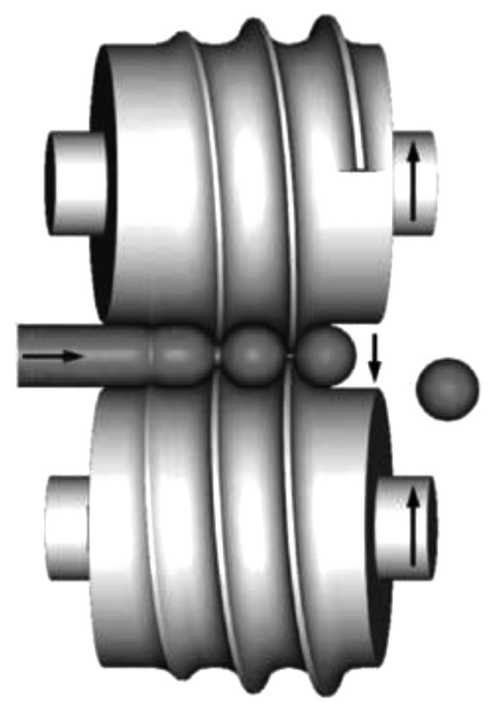

Figure 1: Working principle of $\mathrm{SR}^{5}$

ment, etc. ${ }^{7}$ SR has thus become an interested SBB-manufacturing method for the researchers.

Many publications reported on the steel-ball formation using SR. Z. Pater ${ }^{8,9}$ discussed multi-wedge helical rolling processes for producing steel balls and predicted the distribution of effective strain, temperature and effective stress of steel balls with a diameter of 50 mm. S. C. Yang ${ }^{11}$ developed a mathematical model to design and manufacture a skew roller for producing steel balls. Z. Hu. ${ }^{6}$ carried out a series of SR experiments to study the formation mechanism for steel balls based on an experimental investigation and FE simulation. Q. Cao et al. ${ }^{12}$ designed the helical groove for producing steel balls with cold SR and conducted an FE simulation to predict the forming process, evolution and distribution laws for strain, stress and damage, using the SIMUFACT software. However, few researchers focused on the formation of BSBs with a diameter of $\phi 30 \mathrm{~mm}$ under the warm-SR conditions and predicted its distribution of effective plastic strain, effective strain rate, temperature and effective stress within the BSBs.

The aim of this work is to apply the SR technique to form BSBs with a diameter of $\phi 30 \mathrm{~mm}$ under the warm-SR conditions and reveal the formation mechanism. Firstly, an FE simulation was carried out to predict

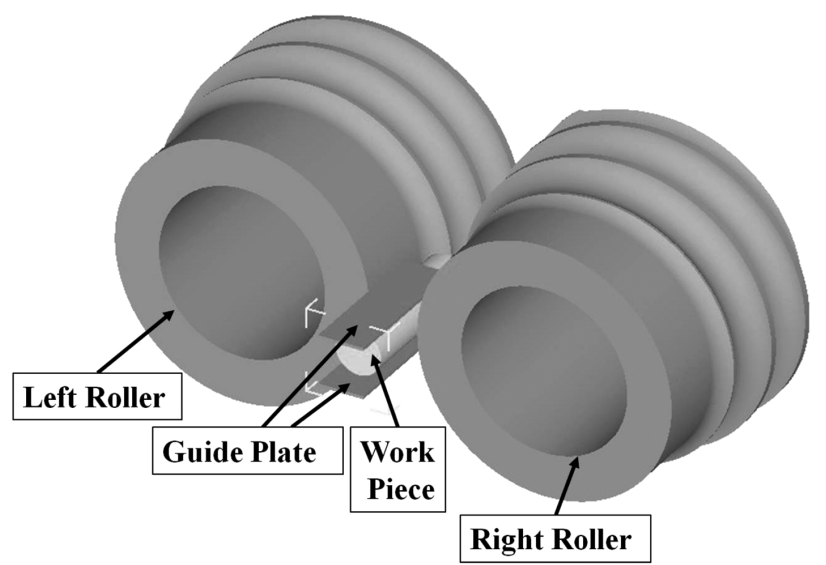

Figure 2: FE model of warm SR

the distribution of effective plastic strain, strain rate, temperature and effective stress of BSBs. Secondly, experimental $\mathrm{SR}$ was performed to validate the FE simulation results.

\section{ESTABLISHMENT OF THE FE SIMULATION SYSTEM FOR SKEW ROLLING}

The stress-strain relationship of bearing steel 52100 from ref. ${ }^{13}$ was used in the FE software Deform-3D to predict the material flow during warm SR. The established FE model of SR is shown in Figure 2. SR is a complicated process and it is necessary to simplify the FE model. The left and righter rollers were set as rigid bodies. The frication between the rollers and the workpiece was defined as a shear-friction model. The workpiece was set as a rigid-plastic body whose material was assumed to be uniform and isotropic. Table 1 shows the property of steel 52100. ${ }^{14}$ The heat conduction and heat capacity are listed in Table 2. ${ }^{15,16}$ The heat transfer coefficient was defined as $40 \mathrm{~N} / \mathrm{s} / \mathrm{mm} /{ }^{\circ} \mathrm{C} .{ }^{17,18}$

The length and diameter of the round-bar workpiece were $100 \mathrm{~mm}$ and $30 \mathrm{~mm}$, respectively. The initial rolling temperature of the workpiece was $750{ }^{\circ} \mathrm{C}$. The temperature of the environment and the roller was $20^{\circ} \mathrm{C}$. To synthesize the computational efficiency and precision, 100,000 tetrahedron elements were used to mesh the workpiece. There were a total of 12,000 simulation steps. The step increment was 0.0001 s. Viewing the

Table 1: Material property of steel 52100

\begin{tabular}{|c|c|c|c|c|}
\hline $\begin{array}{c}\text { Elasticity modulus } \\
(\mathrm{GPa})\end{array}$ & Poisson's ratio & $\begin{array}{c}\text { Coefficient of } \\
\text { thermal expansion } \\
\left(1 /{ }^{\circ} \mathrm{C}\right)\end{array}$ & $\begin{array}{c}\text { Radiation coefficient } \\
\left(\mathrm{N} / \mathrm{s} / \mathrm{mm} /{ }^{\circ} \mathrm{C}^{4}\right)\end{array}$ & $\begin{array}{c}\text { Convection } \\
\text { coefficient } \\
\left(\mathrm{N} / \mathrm{s} / \mathrm{mm} /{ }^{\circ} \mathrm{C}\right)\end{array}$ \\
\hline 208 & 0.29 & $1.1 \mathrm{e}-05$ & 0.8 & $\begin{array}{c}\text { Density } \\
\left(\mathrm{Kg} / \mathrm{m}^{3}\right)\end{array}$ \\
\hline
\end{tabular}

Table 2: Heat conduction and heat capacity of steel 52100

\begin{tabular}{|c|c|c|c|c|c|c|c|c|c|c|}
\hline Temperature $\left({ }^{\circ} \mathrm{C}\right)$ & 100 & 200 & 300 & 400 & 500 & 600 & 700 & 800 & 900 & 1000 \\
\hline Coefficient of heat conduction $\left(\mathrm{W} /\left(\mathrm{m} \cdot{ }^{\circ} \mathrm{C}\right)\right)$ & 41 & 41 & 39.9 & 38.1 & 35.9 & 33.6 & 33.6 & 33.6 & 33.6 & 33.6 \\
\hline Heat capacity $\left(\mathrm{J} / \mathrm{kg} /{ }^{\circ} \mathrm{C}\right)$ & 371 & 451 & 461 & 496 & 533 & 568 & 611 & 677 & 787 & 787 \\
\hline
\end{tabular}


process from the feed end, the two rollers rotate counter clockwise at the same speed of $110 \mathrm{~min}^{-1}$.

\section{SIMULATION ANALYSIS OF THE BSB FORMATION DURING WARM SR}

The microstructure evolution and metal flow depend on the effective plastic strain, effective plastic strain rate, temperature and effective stress. The forming mechanism can be revealed by analyzing the distribution of effective plastic strain, effective plastic strain rate, temperature and effective stress. It is necessary to predict these parameters of bearing steel balls during warm skew rolling.

\subsection{Prediction of the BSB-formation process}

Figure 3 shows the formation process of SR. Figure 3a shows that the workpiece is fed into the SR system. With the squeezing of the roller, the diameter of the connecting neck of the workpiece is gradually reduced as shown in Figure 3b. In the process of warm SR, the workpiece rotates with the two rollers. When the tail connecting neck of the workpiece is also fed into the SR system, the closed middle part of the workpiece gets in touch with the cavity surface of the SR roller. At the same time, the closed middle part of the workpiece is subjected to an axial elongation due to the radial compression as shown in Figure 3c. When one roller rotation is completed, an BSB is formed in the cavity of the roller as shown in Figure 3d.

\subsection{Distribution of the effective plastic strain in an BSB}

Figure 4 shows the distribution of the total effective plastic strain of an BSB in 1.2 s. Figure $4 a$ shows the contour of the effective strain distribution. Figure $\mathbf{4 b}$ shows the longitudinal effective strain distribution. It can be seen from Figure 4 that the maximum effective plastic strain is located in region A, i.e., at both ends of an BSB. However, the effective plastic strain was the smallest in region $\mathrm{C}$, i.e., at the center of an BSB. The

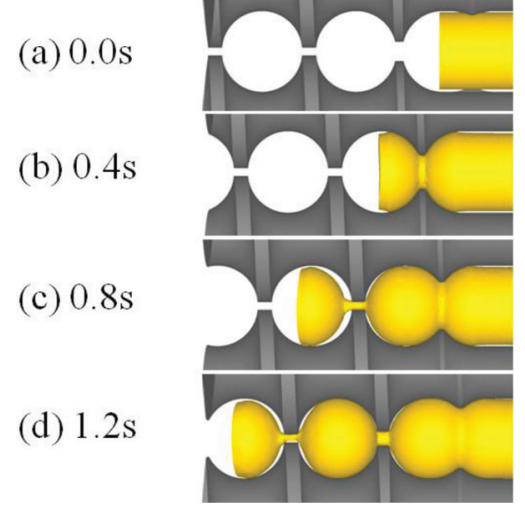

Figure 3: Formation process of SR

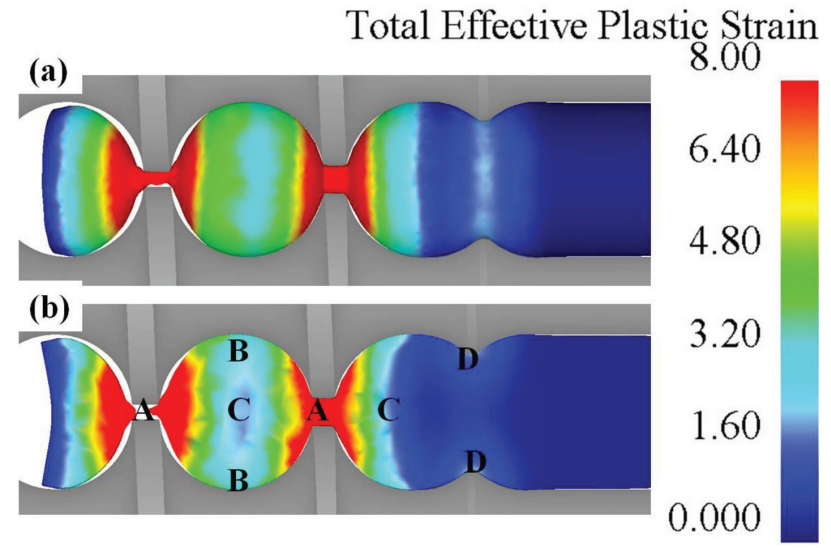

Figure 4: Distribution of the total effective plastic strain of an BSB in $1.2 \mathrm{~s}$

effective plastic strain of region $\mathrm{B}$ is between region $\mathrm{A}$ and region $\mathrm{C}$. This is because region $\mathrm{A}$ is in direct contact with the raised edge and its deformation is serious. In addition, region $\mathrm{B}$ is squeezed by the spiral groove and deformed. Deformation in region $\mathrm{C}$ is due to the metal flow during SR.

\subsection{Distribution of the effective-plastic-strain rate distribution in an $\mathrm{BSB}$}

Figure 5 shows the distribution of the effective-plastic-strain rate of an BSB in $1.2 \mathrm{~s}$. Figure 5a shows the contour of the effective-plastic-strain distribution. Figure $\mathbf{5 b}$ shows the longitudinal effective-plastic-strain distribution. It can be seen from Figure 5 that the maximum effective-plastic-strain rate takes place in regions A, B and D. On the other hand, the minimum effective-plastic-strain rate is located in region $\mathrm{C}$. This is because regions $\mathrm{A}, \mathrm{B}$ and $\mathrm{D}$ are simultaneously in contact with the two rollers, leading to a rapid metal flow and deformation at any time during SR. The material flows and it is then transferred to the center of the workpiece, i.e., in region $\mathrm{C}$.

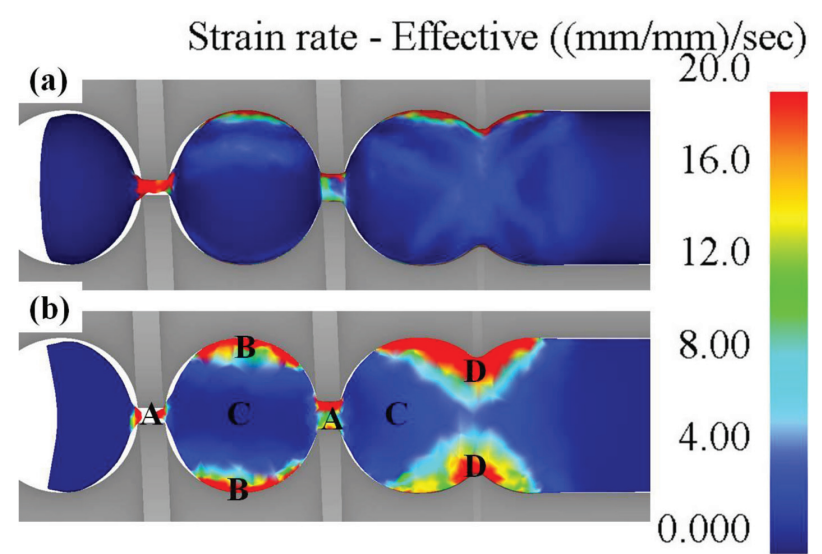

Figure 5: Distribution of the effective-plastic-strain rate of an BSB in $1.2 \mathrm{~s}$ 


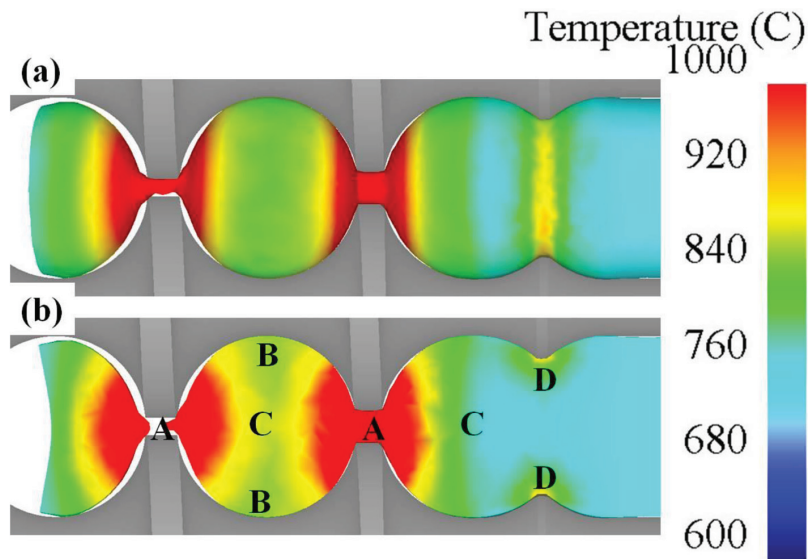

Figure 6: Distribution of the temperature of an BSB in $1.2 \mathrm{~s}$

\subsection{Distribution of the temperature in an BSB}

Figure 6 shows the distribution of the temperature in an BSB in $1.2 \mathrm{~s}$. Figure $6 \mathbf{a}$ shows the contour of the temperature distribution. Figure $\mathbf{6 b}$ shows the longitudinal temperature distribution. It can be seen that the temperature value is maximum at two ends of an BSB. This is due to a larger plastic deformation which leads to a temperature rise. The temperature reached $1000{ }^{\circ} \mathrm{C}$ in region $\mathrm{A}$. However, the temperature in region $\mathrm{B}$ is lowest, i.e., $800{ }^{\circ} \mathrm{C}$. During SR, region B is directly in contact with the roller surfaces so that the heat conduction between the workpiece and roller leads to a heat loss in region $\mathrm{B}$. The temperature in region $\mathrm{C}$ is lower than in region $\mathrm{A}$, but higher than in region $\mathrm{B}$. The temperature in region $\mathrm{C}$ is $900{ }^{\circ} \mathrm{C}$. Region $\mathrm{C}$ is located in the center of an BSB. Larger deformations and heat conduction hardly occur in region $\mathrm{C}$.

\subsection{Distribution of the effective stress in an BSB}

Figure 7 shows the distribution of the effective stress of an BSB in $1.2 \mathrm{~s}$. Figure 7a shows the contour of the effective-stress distribution. Figure $\mathbf{7 b}$ shows the longitudinal effective-stress distribution. It can be seen from Figure 7 that the maximum effective stress distri-

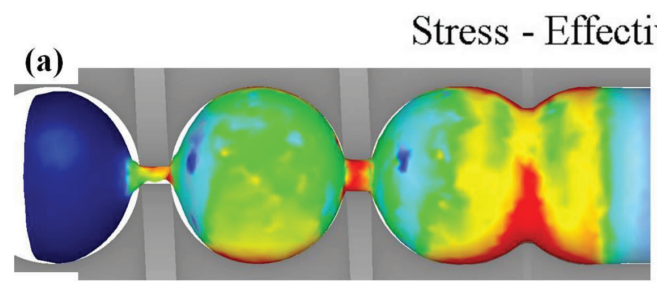

${ }_{300}(\mathrm{MPa})$

(b)

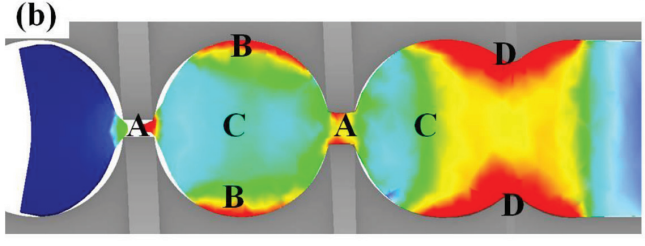

Figure 7: Distribution of the effective stress of an BSB in $1.2 \mathrm{~s}$ butes in regions $\mathrm{A}$ and $\mathrm{B}$, its value reaching $300 \mathrm{MPa}$. In region $\mathrm{A}$, its large plastic deformation and high strain rate result in a high effective stress. Although the plastic deformation in region $\mathrm{B}$ is inferior to that in region $\mathrm{A}$, its higher plastic-strain rate (Figure 5) and lower temperature (Figure 6) also cause a high effective stress. It can be seen from Figures $\mathbf{4}$ and $\mathbf{5}$ that the effective plastic strain and strain rate in region $\mathrm{C}$ are lower than those in regions $\mathrm{A}$ and $\mathrm{B}$. In addition, the final temperature of $885^{\circ} \mathrm{C}$ is higher than the initial temperature of $750{ }^{\circ} \mathrm{C}$ due to plastic heating. These factors determine the effective stress, which is minimum, i.e., $120 \mathrm{MPa}$. Region D is located in the connecting neck of the next BSB. In addition, it is strongly affected by the load of the roller and deformation. Therefore, the effective stress in region $\mathrm{D}$ is also very high.

\subsection{Experimental validation for the $\mathrm{FE}$ simulation of skew rolling}

The SR experiment was carried out using an SR production line. This SR equipment belongs to a horizontal mill of twin rolls. The axes of the left and righter roller intersect with the roller angle. Driven by an electric motor, the two rollers rotate counter clockwise at the same speed.

It is noteworthy that the initial rolling temperature is $750{ }^{\circ} \mathrm{C}$. Table 3 shows the process parameters of the single-screw groove for producing BSBs with a diameter of $\phi 30 \mathrm{~mm}$. The helix angle $\beta$ of the single-screw groove can be calculated by means of function $\tan \beta=S /\left(\pi \cdot D_{\alpha}\right)$ (where $S$ is the helical pitch of the screw groove in a roller and $D_{\alpha}$ is the rotation diameter of the rollers at the

Table 3: Process parameters of the single-screw groove for producing BSBs with a diameter of $\phi 30 \mathrm{~mm}^{6}$

\begin{tabular}{|l|c|}
\hline \multicolumn{1}{|c|}{ Process parameters } & Value \\
\hline Diameter of the roller $/ \mathrm{mm}$ & 200 \\
\hline Roller angle / & 2.5 \\
\hline Rotational speed of the roller $/ \mathrm{min}^{-1}$ & 110 \\
\hline Radius of the V groove /mm & 15.6 \\
\hline Radius of the out-feed groove /mm & 3.5 \\
\hline Length of the flange / & 1080 \\
\hline Height of the initial flange $/ \mathrm{mm}$ & 2 \\
\hline Width of the initial flange $/ \mathrm{mm}$ & 1.7 \\
\hline Height of the finishing flange $/ \mathrm{mm}$ & 14.6 \\
\hline Width of the finishing flange $/ \mathrm{mm}$ & 5.5 \\
\hline
\end{tabular}

(a) Predicted results

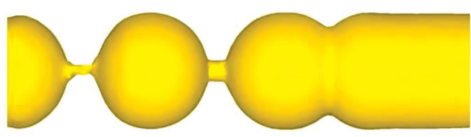

(b) Experimental results

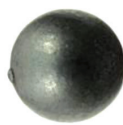

Figure 8: Comparison of BSB shapes of the predicted and experimental results 
cross point), i.e., the helix angle is $3^{\circ}$. Generally, the roller angle is lower than the helix angle. For our experiment, the roller angle was defined as $2.5^{\circ}$. The rotational speed of the roller was $110 \mathrm{~min}^{-1}$.

The warm-SR experiment was conducted through three steps. In step 1, two rollers were manufactured according to the above process parameters. The workpieces were prepared using a round bar of bearing steel 52100. In step 2, the round bar with a diameter of $30 \mathrm{~mm}$ and length of $100 \mathrm{~mm}$ was heated to $800{ }^{\circ} \mathrm{C}$ and held at this temperature for about one hour, then transferred to the SR production line. The initial rolling temperature was $750{ }^{\circ} \mathrm{C}$ due to the heat loss during the transfer of the workpieces. In step 3, an SR machine was activated to form BSBs. The workpiece was fed and rotated with the two rollers. BSBs with a diameter of $30 \mathrm{~mm}$ were produced using the warm-SR machine.

In order to validate the FE simulation, a comparison between the predicted and experimental results was carried out. Figure 8 shows the comparison of the BSB shapes of the predicted and experimental results. Furthermore, ten different positions from ten BSB specimens were randomly selected to measure the diameters of the predicted and experimental BSBs. Table 4 shows the comparison of BSB sizes of the predicted and experimental outcomes. It can be seen from Figure $\mathbf{8}$ and Table 4 that the predicted BSB was consistent with the experimental BSB. Moreover, the difference in the BSB size between the predicted and experimental results was less than $5 \%$. This indicates that the developed FE simulation was capable to accurately predict the formation of BSBs using SR. In addition, the formation mechanism for BSBs can be revealed using the developed FE simulation system of warm SR.

Table 4: Comparison of BSB sizes of the predicted and experimental results

\begin{tabular}{|c|c|c|c|}
\hline $\begin{array}{c}\text { Randomly } \\
\text { selected } \\
\text { diameter }\end{array}$ & $\begin{array}{c}\text { Experimental } \\
\text { value }\end{array}$ & $\begin{array}{c}\text { Predicted } \\
\text { value }\end{array}$ & Error/\% \\
\hline D1 & 30.96 & 31.25 & 0.94 \\
\hline D2 & 31.07 & 32.06 & 3.19 \\
\hline D3 & 31.29 & 30.68 & 1.95 \\
\hline D4 & 31.18 & 31.53 & 1.12 \\
\hline D5 & 31.24 & 30.95 & 0.93 \\
\hline D6 & 31.15 & 31.32 & 0.55 \\
\hline D7 & 31.20 & 31.74 & 1.73 \\
\hline D8 & 31.12 & 31.43 & 1.00 \\
\hline D9 & 31.14 & 31.64 & 1.61 \\
\hline D10 & 31.16 & 31.18 & 0.06 \\
\hline
\end{tabular}

\section{CONCLUSIONS}

An FE simulation system of SR was established to predict the formation and distribution of the effective plastic strain, strain rate, temperature and effective stress in an BSB during warm SR. The FE-simulation results show that the total plastic strain was the smallest in the centre of the BSB. However, the total plastic strain was maximum at two ends of the BSB due to the squeezing of the raised edge within the two rollers. The total plastic strain at the equator of the BSB was lower than that at the two ends, but larger than in the centre of the BSB. Additionally, the FE strain-rate distribution shows that the plastic-strain rate was maximum at two ends and the equator of the BSB due to a direct contact of the workpiece and the two rollers. The plastic-strain rate in the centre of the BSB was minimum because of a lower rate of the metal flow.

The FE temperature distribution shows that the temperature reached $1000{ }^{\circ} \mathrm{C}$ at two ends of the BSB, which is maximum. This is because a larger plastic deformation leads to a temperature rise within an BSB. Although some plastic deformation generated heat at the equator of the BSB, the heat loss increased with the heat conduction between the workpiece and the two rollers. Therefore, the temperature at the equator of the BSB was minimum, i.e., about $800{ }^{\circ} \mathrm{C}$. The temperature in the centre of the BSB was $900{ }^{\circ} \mathrm{C}$.

The FE effective-stress distribution shows that the maximum stress was located at the two ends and the equator of the BSB, being $300 \mathrm{MPa}$. The effective stress in the center of the BSB was minimum, about $120 \mathrm{MPa}$. A lower plastic strain, lower strain rate and a higher final temperature caused a lower deformation resistance in the center of the BSB.

A series of process parameters were designed to manufacture the rollers of SR. To validate the FE simulation, warm SR was conducted under the following process conditions: the initial temperature of $750{ }^{\circ} \mathrm{C}$, roller angle of $2.5^{\circ}$ and rotational speed of $110 \mathrm{~min}^{-1}$. After the warm SR, an BSB with a diameter of $\phi 30 \mathrm{~mm}$ was produced, using an SR machine.

Comparing the experimental and predicted results for BSBs, we found that the predicted BSB was consistent with the experimental BSB. Moreover, the difference in the BSB size between the predicted and experimental results was less than $5 \%$. This indicates that the BSB formation mechanism can be revealed, using the developed FE simulation of warm SR.

\section{Acknowledgment}

This project is funded by the National Natural Science Foundation of China (Grant No. 51805314), the National Key Research and Development Program of China (Grant No. 2018YFB1307900), the Shanghai Science and Technology Commission (Grant No. 16030501200) and the Shanghai University of Engineering and Science (Grant Nos. E3-0903-17-01006 and E3-0501-18-01002). The Robot Functional Materials Preparation Laboratory from the Shanghai University of Engineering Science is also gratefully acknowledged. 


\section{Y. HUO et al.: FORMING ANALYSIS OF STEEL BALL BEARINGS MADE WITH WARM SKEW ROLLING}

\section{REFERENCES}

${ }^{1}$ J. Ding, Fault detection of a wheelset bearing in a high-speed train using the shock-response convolutional sparse-coding technique, Measurement, 117 (2018), 108-124, doi:10.1016/j.measurement. 2017.12.010

${ }^{2}$ T. He, Y. Huo, A New Damage Evolution Model for Cold Forging of Bearing Steel-Balls, Transactions of the Indian Institute of Metals, 71 (2018) 5, 1175-1183, doi:10.1007/s12666-017-1253-0

${ }^{3}$ J. Tomczak, Z. Pater, T. Bulzak, Designing of screw impressions in the helical rolling of balls, Archives of Civil \& Mechanical Engineering, 14 (2014) 1, 104-113, doi:10.1016/j.acme.2013.07.004

${ }^{4}$ C. C. Hsu, J. H. Huang, W. C. Chen, Y. K. Fuh, Numerical analysis and experimental validation on multi-stage warm forging process of deep groove ball bearing - a modified punch geometry with microstructure and defect analysis, International Journal of Advanced Manufacturing Technology, 89 (2017) 5-8, 2119-2128, doi:10.1007/s00170-016-9218-8

${ }^{5}$ Z. Hu, B. Wang, Z. Zheng, Research and industrialization of near-ne rolling technology used in shaft parts, Frontier Mechanical Enginnering, 13 (2018) 1, 17-24, doi:10.1007/s11465-018-0480-3

${ }^{6} \mathrm{Z}$. Hu, B. Wang, Z. Zheng, Metal flow law of steel ball forming by skew rolling, Chinese Journal of Engineering, 37 (2015) 1, 782-788, doi:10.13374/j.issn.2095-9389.2015.06.016

${ }^{7}$ F. L. Mao, Y. H. Shuang, Q. H. Wang, F. J. Wang, Y. J. Gou, C. J. Zhao, Theoretical and Experimental Study of the Tandem Skew Rolling Process, Steel Research International, 89 (2018) 8, doi:10.1002/srin.201800022

${ }^{8}$ Z. Pater, Numerical analysis of helical rolling processes for producing steel balls, International Journal of Materials \& Product Technology, 53 (2016) 2, 137-153, doi:10.1504/IJMPT.2016.076417

${ }^{9}$ Z. Pater, J. Tomczak, J. Bartnicki, M. R. Lovell, P. L. Menezes, Experimental and numerical analysis of helical-wedge rolling process for producing steel balls, International Journal of Machine Tools \& Manufacture, 67 (2013), 1-7, doi:10.1016/j.ijmachtools. 2012.12.006
${ }^{10}$ A. Stefanik, P. Szota, S. Mroz, H. Dyja, Application of the three-high skew rolling to magnesium rods production, Materials Testing, 58 (2016) 5, 438-441, doi:10.3139/120.110876

${ }^{11}$ S. C. Yang, C. K. Chen, The surface geometry of rollers with skew rolling of steel balls, Proceedings of the Institution of Mechanical Engineers, Part C: Journal of Mechanical Engineering Science, 215 (2001) 5, 523-532, doi:10.1243/0954406011520922

${ }^{12}$ Q. Cao, L. Hua, D. S. Qian, Finite element analysis of deformation characteristics in cold helical rolling of bearing steel-balls, Journal of Central South University, 22 (2015) 4, 1175-1183, doi:10.1007/ s11771-015-2631-6

${ }^{13}$ Y. Huo, T. He, S. Chen, R. Wu, Mechanical Behavior and Microstructure Evolution of Bearing Steel 52100 During Warm Compression, JOM, 70 (2018) 7, 1112-1117, doi:10.1007/s11837018-2914-0

${ }^{14}$ H. Hwang, B. C. De Cooman, Influence of the Initial Microstructure on the Spheroidization of SAE 52100 Bearing Steel, Steel Research International, 87 (2016) 1, 112-125, doi:10.1002/srin.201400591

${ }^{15}$ S. Gu, L. Zhang, C. Yue, J. Ruan, J. Zhang, H. Gao, Multi-field coupled numerical simulation of microstructure evolution during the hot rolling process of GCr15 steel rod, Computational Materials Science, 50 (2011) 7, 1951-1957, doi:10.1016/j.commatsci.2011. 01.034

${ }^{16}$ S. Gu, L. Zhang, J. Ruan, H. Mei, Y. Zhen, X. Shi, Multi-field coupled numerical simulation of hot reversible rolling process of GCr15 steel rod, 11th International Conference on Numerical Methods in Industrial Forming Processes, 1532 (2013), 354-360, doi: $10.1063 / 1.4806846$

${ }^{17}$ C. Yue, L. Zhang, J. Ruan, H. Gao, Modelling of recrystallization behavior and austenite grain size evolution during the hot rolling of GCr15 rod, Applied Mathematical Modelling, 34 (2010) 9, 2644-2653, doi:10.1016/j.apm.2009.12.001

${ }^{18}$ Y. Huo, T. He, S. Chen, H. Ji, R. Wu, Microstructure evolution and unified constitutive equations for the elevated temperature deformation of SAE 52100 bearing steel, Journal of Manufacturing Processes, 44 (2019), 113-124, doi:10.1016/j.jmapro.2019.05.051 